\title{
2D gravity qualitative modeling to identify bedrock and volcanic rocks in South Lampung region
}

\author{
Ahmad Zaenudin ${ }^{1 *}$, I Gede Boy Darmawan ${ }^{1,2}$, George Laimeheriwa ${ }^{3}$ \\ ${ }^{1}$ Department of Geophysical Engineering, Faculty of Engineering, Universitas Lampung, Bandar Lampung, Indonesia \\ ${ }^{2}$ Unila Geoscience Research Tim, Faculty of Engineering, Universitas Lampung, Bandar Lampung, Indonesia \\ ${ }^{3}$ Institute of Mineral Resources Engineering, Wulnerstabe 2, 52062 Aachen, Germany
}

*Corresponding Address: ahmad.zaenudin@eng.unila.ac.id

\begin{tabular}{|c|c|}
\hline Article Info & ABSTRACT \\
\hline Article history: & Gravity measurement has been conducted in South Lampung area to study \\
\hline $\begin{array}{l}\text { Received: January } 18^{\text {th }}, 2020 \\
\text { Accepted: April } 26^{\text {th }}, 2020 \\
\text { Published: April } 30^{\text {th }}, 2020\end{array}$ & $\begin{array}{l}\text { the characteristics of the distribution of bedrock and igneous rocks, } \\
\text { especially those that can be utilized for development in the National } \\
\text { Strategic Area of the Sunda Strait. This study uses a 2D qualitative modeling } \\
\text { method and utilizing spectrum analysis of complete Bouguer anomaly data. }\end{array}$ \\
\hline Keywords: & $\begin{array}{l}\text { Based on the result of modeling of residual gravity anomaly, it was found } \\
\text { that the intrusion pattern on Sulan granitoid pluton and surrounding plutons }\end{array}$ \\
\hline $\begin{array}{l}\text { Bakauheni; } \\
\text { Bedrock; } \\
\text { Gravity; } \\
\text { Tarahan; } \\
\text { Volcanic rock. }\end{array}$ & $\begin{array}{l}\text { showed a significant intrusion of the body and scattered in some Tarahan } \\
\text { area. 2D qualitative modeling shows Paleozoic metamorphic rocks are } \\
\text { responsible as bedding rocks, and the spread was identified scattered } \\
\text { throughout the study area, although it cannot be ascertained whether the } \\
\text { bedrock in the Bakauheni area is precisely the same rock as the bedrock in } \\
\text { Tarahan area. Meanwhile, Quaternary volcanic rocks are still dominated by } \\
\text { tuffaceous sandstone and breccia. This method also confirms that andesite } \\
\text { lava is commonly found as a product of the eruption of Mount Rajabasa and } \\
\text { Pre-Rajabasa in the Bakauheni region. Nevertheless, some potential of } \\
\text { basaltic andesite rocks can be obtained in monogenetic volcanic zones } \\
\text { exposed around the foot of Mount Rajabasa. }\end{array}$ \\
\hline
\end{tabular}

(C) 2020 Physics Education Department, UIN Raden Intan Lampung, Indonesia.

\section{INTRODUCTION}

Subduction pressures released along the Sumatra front arc are characterized by the presence of faults in the direction of the tectonic plate (Barber et al., 2005). This faults known as the Sumatra fault system that are composed of various faults segment. One of those fault are Lampung-Panjang fault residing in the research area. Most of the research area located in South Lampung (Tarahan - Bakauheni), which is Lampung High Structural (Yudhicara et al., 2017). This location is also known as part of strategic programs development in Sunda Strait region (Haerudin et al., 2018).

For the study of subsurface geometry of bedrock and above, it can be described with geophysical data, which in this study using gravity data. Measurements of gravity to identify lithology and geological structures have been widely used, from the deep crust to sedimentary rocks close to the surface (Zahra \& Oweis, 2016). A gravity method is a useful tool in inferring subsurface structures since it implies a density distribution within the earth and is used to reverse tectonic pressures (Xu et al., 2015).

The purpose of this study is to study the characteristics of the distribution of bedrock and volcanic rocks, especially those that can use for development in the National Strategic Area of the Sunda Strait. The gravity model helps to understand the model of bedrock and the spread of volcanic rock 
that can use as raw material. The $2 \mathrm{D}$ gravity qualitative model will show the subsurface rock layers as a new approach to mapping the potential area of raw material. Robust calculation and estimation of resources can be done using the results of this model to support the development of the National Strategic Area of the Sunda Strait as part of The Masterplan for acceleration and expansion of Indonesia's economic development (MP3EI).

\section{METHODS}

Gravity measurement has been done to obtain a subsurface model related to the dissemination of bedrock and volcanic igneous rocks in the study area. This measurement is used LaCoste \& Romberg778 gravimeter from $6^{\text {th }}$ October to $30^{\text {th }}$ November 2016. The acquisition was conducted throughout the TarahanBakauheni area as much as 478 acquisition points as primary data.

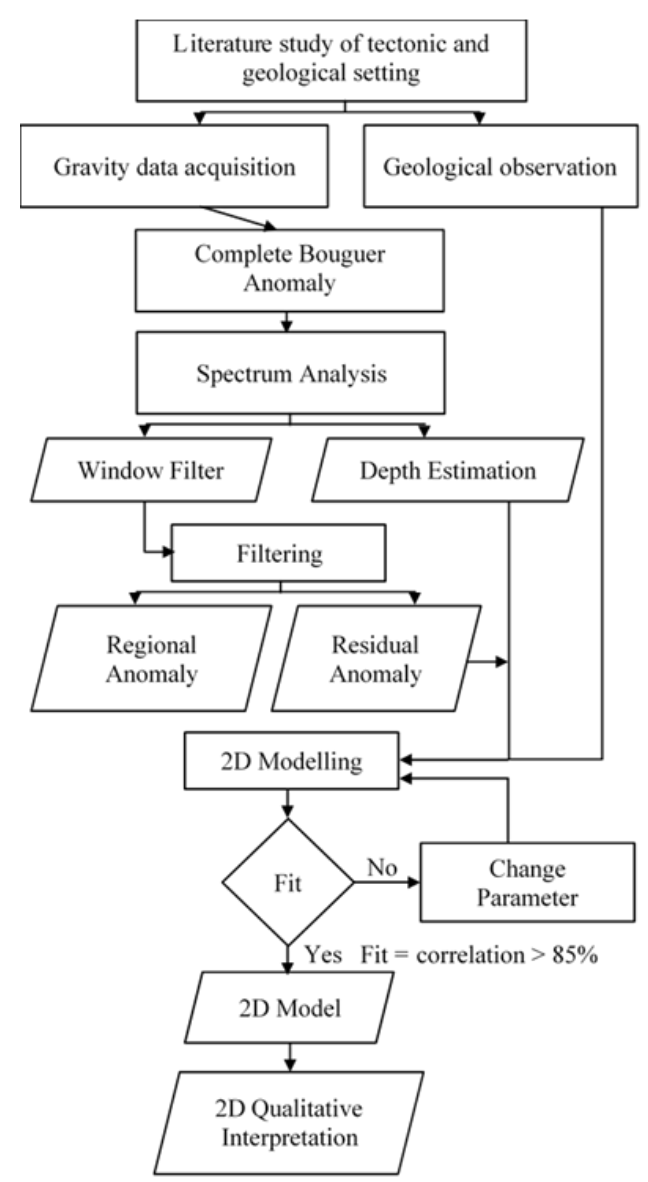

Figure 1. The Workflow of the Study
The sampling method is mostly random, only in the part of Mount Rajabasa that uses the track with inter-point intervals in one track is $1 \mathrm{~km}$, and the distance between tracks is $2 \mathrm{~km}$. Some measurement points are also carried out outside the focus area to minimize ambiguity at the interpolation boundaries. The flow chart of this study is shown in Figure 1.

This research is also conducting the literature study of tectonic and geological setting to get the existing geological features in Tarahan - Bakauheni. Geological features are essential to building the preliminary model of gravity. The 2D modeling process has been input the geological structure and rock formation to the preliminary model. The tectonic and geological setting of Tarahan - Bakauheni described below.

\section{Tectonic Setting}

The tectonic process in the research area (Tarahan-Bakauheni) is inseparable from the tectonic events in Lampung and Semangka Bay, as well as the transition zone from tilted to normal subduction in the Sunda Strait. Semangka and Lampung-Panjang Fault are estimated as a canal from the Ranau-Suoh Fault that is separated around Suoh and Ulubelu and continually to the southeast to form the depression area in Semangka Bay and Lampung Bay. The change in the direction of subduction in the Sunda Strait leads to a complex accretion zone and is indicated by a series of parallel basins, anticlinal ridges, and some rising faults (Agustawijaya, 2019; Harahap et al., 2015).

Tarahan-Bakauheni areas are mostly located in the old volcanic region with one young volcanic area in Mount Rajabasa (Bronto et al., 2012). These old volcanic occurrences show that the study area is in the back arc region. This region dominating the Tarahan area with evidence of granite and granodiorite plutons.

The seismic activity occurring in the Sunda Strait to the West towards Bakauheni shows an increase in the depth of the 
hypocenter. That condition is related to the subduction pattern of the plates in TarahanBakauheni that deepens, although some recorded earthquake events have a shallow hypocenter. One of the evidence of magmatic activity caused by subduction performances in the research area is the existence of the Mount Rajabasa volcanic system. The current volcanic system is a volcanic cone reconstruction of preRajabasa.

\section{Geological Setting}

The oldest rock outcrops in the study area were dominated by Paleozoicum period rocks (Iqbal et al., 2019). This rock formation is exposed only in the Tarahan area surrounding the Cretaceous-Tertiary intrusive rocks (Figure 2). This location became one of the areas that reflect the height of Lampung due to the exposure of Paleozoikum old rocks. Nevertheless, the unit of bedrock formation is not uncovered in the south or the Bakauheni area. Schist rocks dominate the units of rock formations composed of metamorphic rocks. The schist in Tarahan consists of two types, namely quartz-mica and amphibole schist. Pretertiary metamorphic rocks exposed as bedrock are interpreted as products of Menanga Formation metamorphism derived from deep-sea sediments (De Coster, 1974; Henstock et al., 2016).

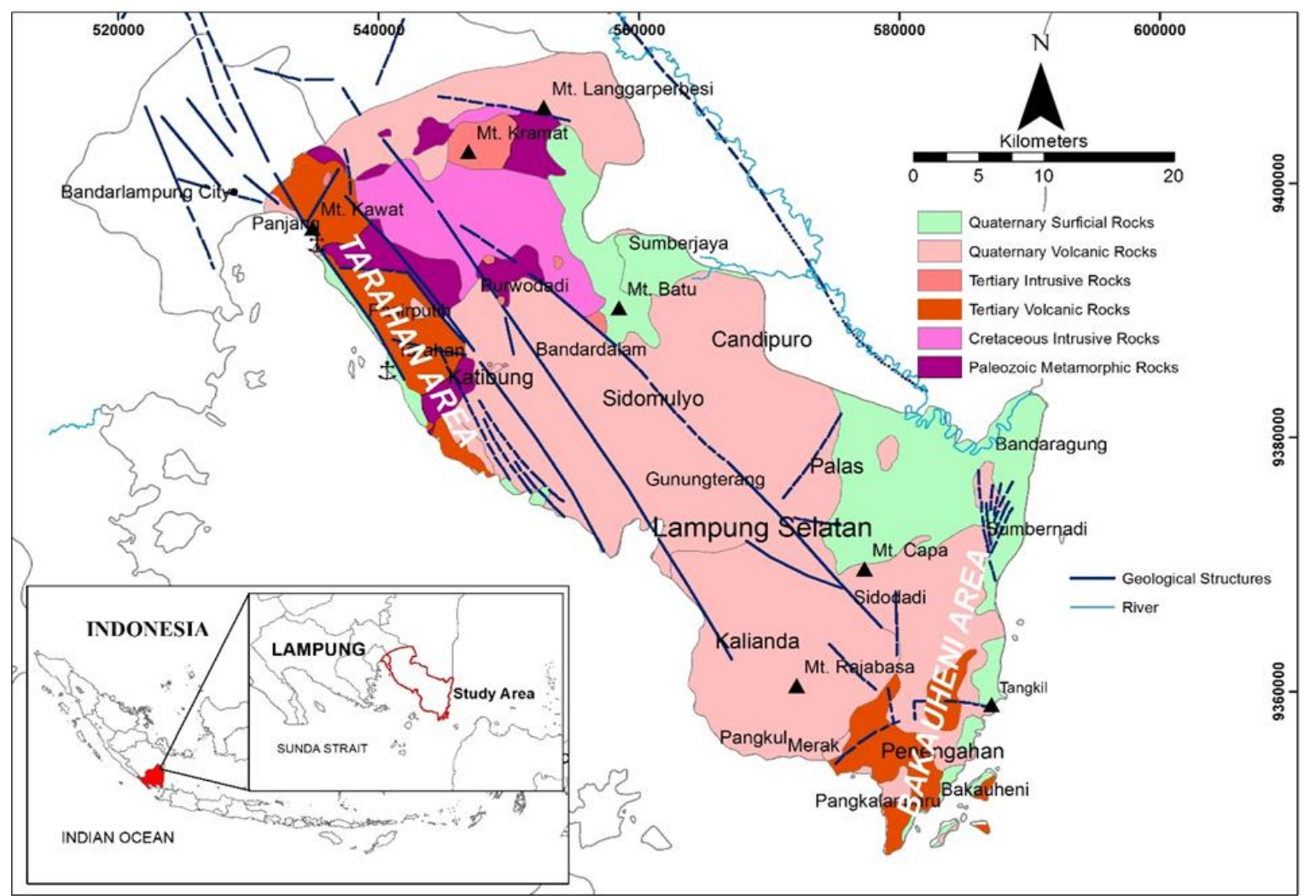

Figure 2. Geological Map Showing the Geological Conditions of the Tarahan and Rajabasa Regions. There Are Six Groups of Rock from Paleozoic to Quaternary with Volcanic, Intrusive, and Metamorphic Lithology.

Sediments derived from volcanic arcs deposited in troughs or fore-arc environments are deformed during the study sites, particularly the Tarahan area. The contacts of these two pre-tertiary rocks were described as occupied by a friction breccia (Kurnio, 2019; Setiady \& Sarmili, 2005). Cretaceous intrusive rocks are Cretaceousdominated rocks that dominate in the Tarahan area with intrusive body conditions 
between granite and granodiorite. These rocks are grouped in Cretaceous intrusive rock units that are identified extending to the western region of Lampung Province (Yudhicara et al., 2017). The largest intrusive rock group in this area is called Sulan Pluton with a grayish white-grained, medium-grained hornblende mineral composition and belonging to the I-type granitoid group. Granitoids of the same type (type I) in this area are also composed of diorite and granite plutons.

Quaternary rocks are dominated by volcanic rocks composed of tuff and tuffaceous compositions. The spread of tuff rock known as Lampung Tuff is extensive, from the Tarahan area to Bakauheni, with dominance more than $50 \%$ of the research area. Quaternary volcanic rocks with a basal andesite lava composition can be found in the Mount Rajabasa area. Rajabasa Mountain is dominated by pyroxenehornblende andesite lava and some pyroclastic rocks in the southern part (Darmawan et al., 2015). While in Tarahan area, Lampung Tuff rock dominated by welded tuff, tuffaceous sandstone, and tuffaceous claystone.

\section{Gravity Data and Processing}

Gravity data measurement results are made to various kinds of correction to get a complete Bouguer anomaly (Khan et al., 2018; Panjaitan \& Astawa, 2016; Salapare et al., 2015). Spectrum analysis was performed to determine the regional and residual zone boundary characteristics of gravity anomalies (Karunianto et al., 2017; Purnomo et al., 2016; Subagio \& Patmawidjaya, 2013; Subarsyah \& Priohandono, 2009). This method separates the influence of the regional gravity response from the complete Bouguer anomaly data. Bouguer anomaly data will be separated from regional influences and obtain residual/local anomaly responses (Ayala et al., 2016; Madu \& Mosto, 2016). It is, therefore, essential to perform spectrum analysis in order to determine the boundary of the filter window by using Fourier transform equations.

$$
F\left(g_{z}\right)=2 \pi G m e^{|k|\left(z_{0}-z_{1}\right)}, z_{1}>z_{0}
$$

Assuming that the mass density is random and there is no correlation between each gravity value and $m=1$ the equation becomes:

$$
\begin{aligned}
& A=C e^{|k|\left(z_{0}-z_{1}\right)} \\
& \ln A=\left(z_{0}-z_{1}\right)|k|+\ln C
\end{aligned}
$$

So, the equation can be analogous to the equation of a straight line. The regional and residual zone boundaries can be obtained from the relationship between $\ln A$ and $k$ (Giacomini et al., 2017; Lo et al., 2018; Putra et al., 2016). The curve of the spectrum analysis results used to determine the width of the window in the splitting of the regional gravity anomaly response and residual/local gravity anomaly (Girolami et al., 2017; Timur et al., 2019) as shown in Figure 3.
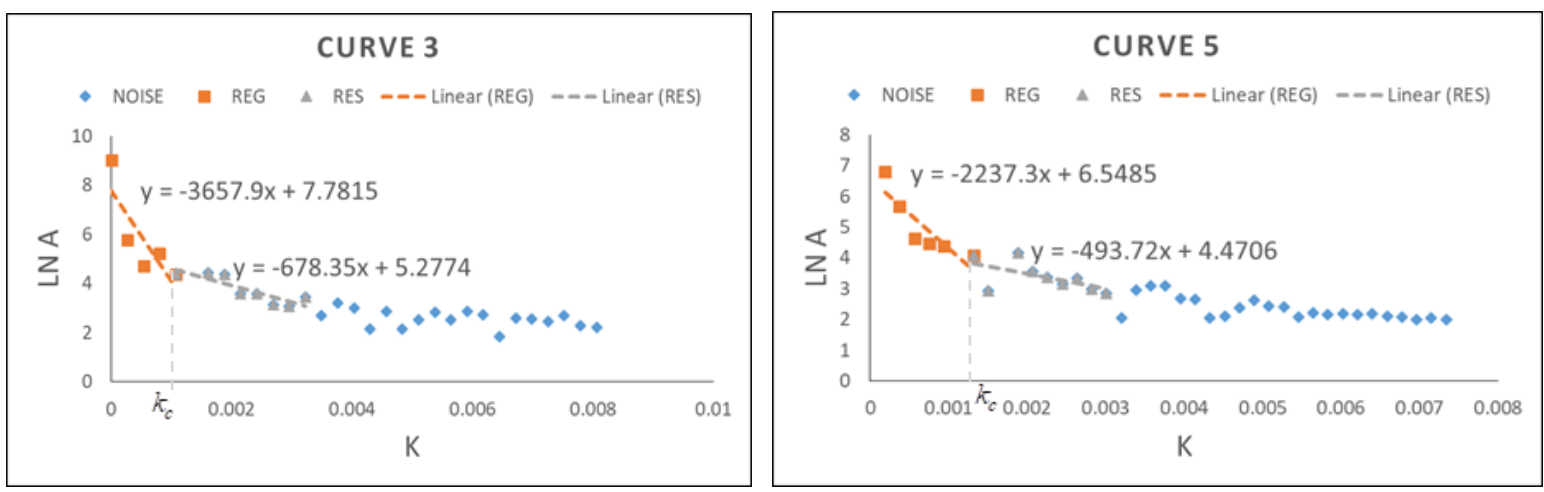

Figure 3. Two of Seven Spectrum Analysis Results to Determine the Width of the Window in the Splitting of the Regional and Residual Gravity Anomaly Response. 
A straight-line gradient analysis of $\ln A$ and $k$ charts can be determined the cut-off point $\left(k_{c}\right)$ or the intersection of the regional and residual line equations used to determine the $N$ value as the window width of the moving average filter (Liu et al.,
2018). The $N$ value is obtained by using the equation 4:

$$
N=\frac{2 \pi}{k_{c} \times \Delta x}
$$

Table 1. Distribution of Spectrum Analysis Results for the Value of the Moving Average Window Width

\begin{tabular}{ccc}
\hline Line & $\begin{array}{c}\text { Wave } \\
\text { Number }(\mathrm{k})\end{array}$ & Window Filter \\
\hline 1 & 0.00081 & 38.605 \\
2 & 0.00105 & 29.842 \\
3 & 0.00161 & 19.490 \\
4 & 0.00147 & 21.239 \\
5 & 0.00131 & 23.845 \\
6 & 0.00093 & 33.697 \\
7 & 0.00081 & 38.480 \\
average & & 29.314 \\
\hline
\end{tabular}

with $\Delta x$ is a space domain in Fast Fourier Transform (FFT). This study used a value of 200 for each line. The result of the spectrum analysis obtained the width of the window for each line, as shown in Table 1. With the results shown in the table, the value of the filter window used to separate regional and local anomalies is $29 \times 29$.

\section{RESULTS AND DISCUSSION}

The result of a complete Bouguer anomaly treatment conducted by the research area is shown in Figure 4. These results show a high anomalous pattern in the Sulan granitoid area and form a pattern resembling plutons. It is inseparable from the geological conditions that indicate the presence of intrusive bodies in the region.

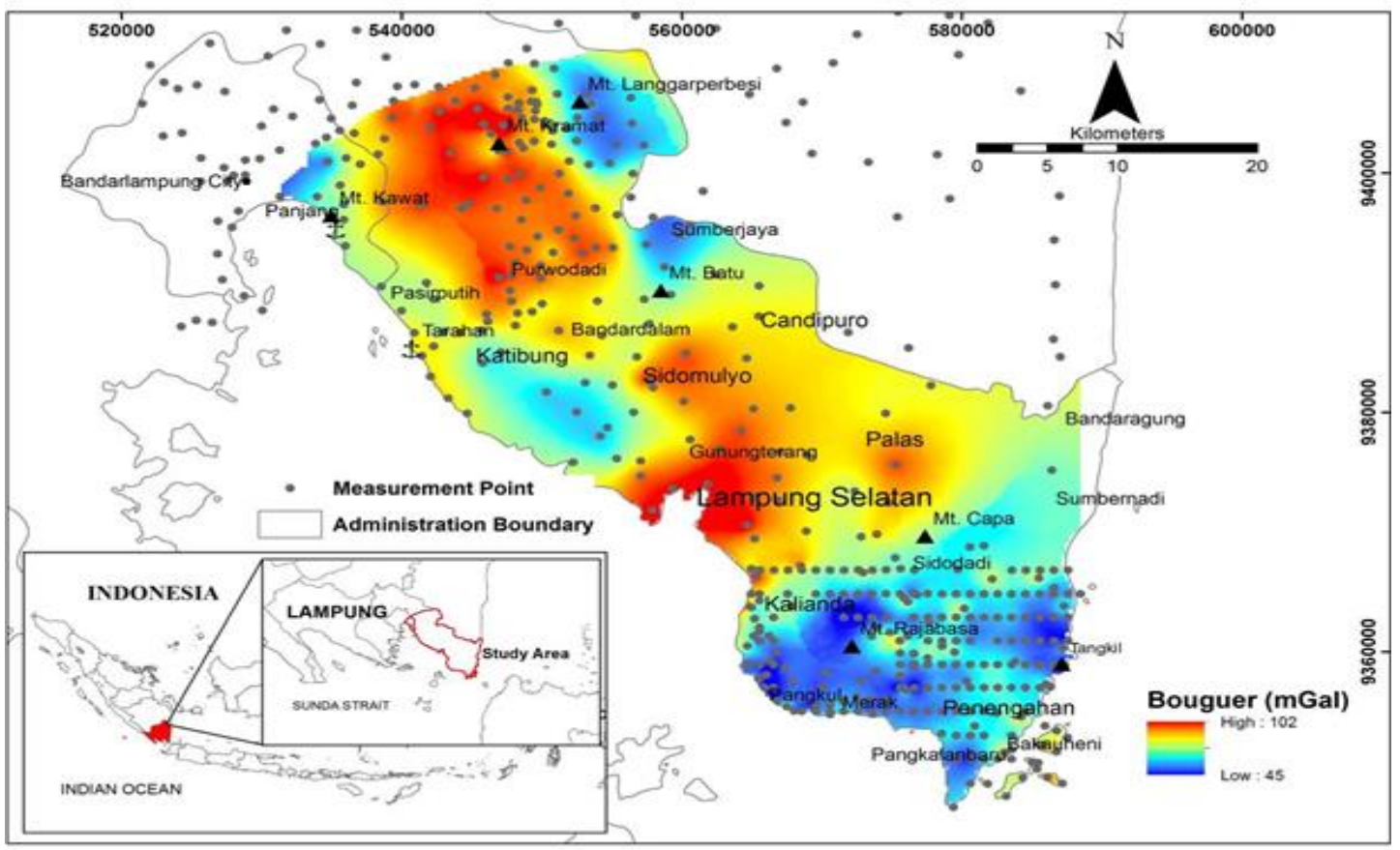

Figure 4. Complete Bouguer Anomaly Map of the Research Area. Red Color Indicates High Anomalous Values, and Blue Indicates Low Anomalous Values. Grey Dots Are Gravity Acquisition Points 
Other high anomalies appear in the area between Tarahan and Bakauheni, with the spreading towards the higher shore. This condition remains unconfirmed whether it relates to intrusion pluton or not. An exciting condition as seen from the low anomalous response in the area of Mount Rajabasa. This condition contrasts with the high anomaly in the northern part, indicating a different limit of rock density. The existence of a low anomaly in Mount Rajabasa can be attributed to the existence of geothermal potential in this region, and this condition is also affected by the fracture zone so that the geothermal fluid can appear on the surface as a manifestation of geothermal.

In the area of Bakauheni, which geologically is the location of tertiary volcanic rock exposure has the distribution of anomalous values that are high too. The outcrop of tertiary volcanic rock in the Bakauheni area is thought to be the remains of the pre-Rajabasa caldera wall rock. Based on the anomalous response in this area, the medium to high anomaly response is responsible for the tertiary volcanic rocks.

In the Tarahan area, particularly in quaternary volcanic rock outcrops, the Bouguer anomaly response shows a low value and appears to be a firm boundary between this region and the Sulan granitoid pluton area. This is interesting considering that in the region, there is a TarahanPanjang Fault that is supposed to be a strikeslip fault. However, if it is perceived from the pattern that appears in the Bouguer anomaly response, it appears that the condition is more likely to lead to a normal fault. To get an overview related to these conditions, then in this study, conduct 2D modeling.

\section{Regional and Residual Anomaly}

The previous application is to obtain filter to the moving average technique results in low pass filter with low frequency from Bouguer anomaly showing the regional anomaly of the research area (Figure 5). The pattern indicated by the regional anomaly is a high anomaly in the severity area to the foot of Rajabasa Mountain and stopped in contrast to the low anomaly, but quantitatively it shows a high anomalous pattern that is between $62-82$ mGal. Residual anomalies use shorter wavelengths and higher frequencies, resulting in a shallower depth of objects. Residual/local anomalies have a range of values between -19 to $16 \mathrm{mGal}$ with a more complex pattern of the regional anomalies.
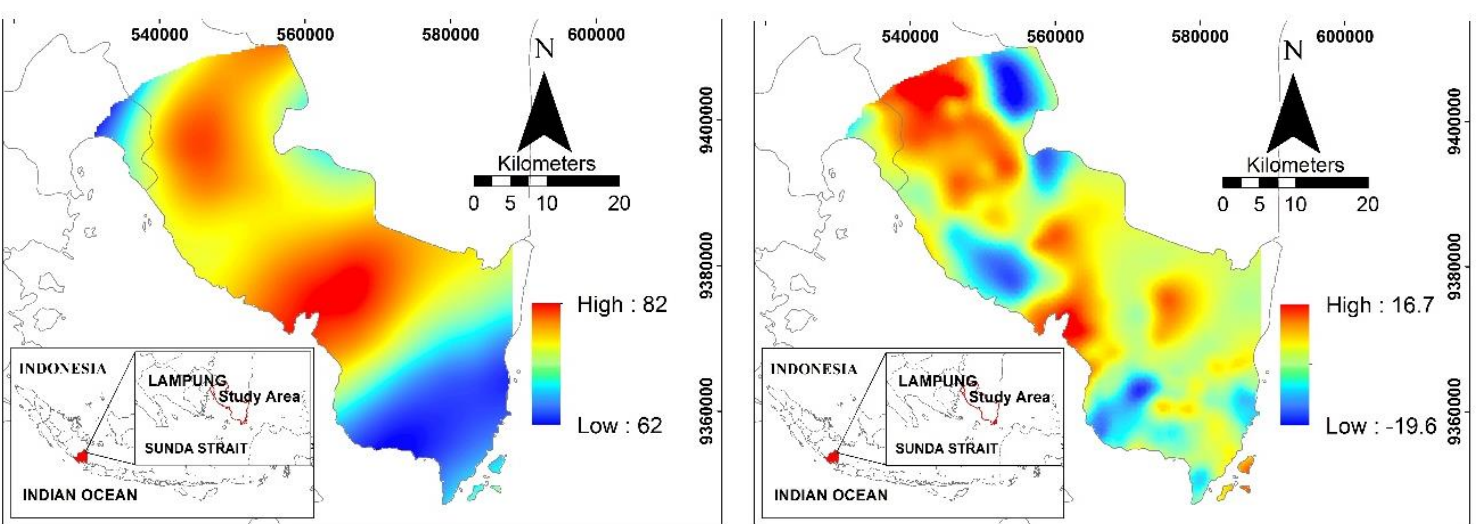

Figure 5. Regional and Residual Gravity Anomaly Map in the Research Area Has Shown That Regional Gravity Anomaly Is Dominated by High Anomaly Pattern and Residual Gravity Anomaly Resembles the Bouguer Anomaly Pattern

An anomaly pattern with a high response is again visible on the granitoid Pluton area clear. This pattern makes the interpretation of the Sulan Pluton granitoid more convincing with a broad and deep intrusion body. The density contrast in the Lampung- 
Panjang Fault area is also increasingly apparent with low and NW-SE directed anomaly patterns. What about the high anomaly in the middle between the Tarahan and Bakauheni areas. This condition will be further examined by creating a 2D model on the track that passes through the area.

Patterns are also interesting to appear around Mount Rajabasa and Tarahan area. Areas were previously identified as responses from tertiary volcanic rocks become more apparent with high anomalous values and form patterns according to tertiary volcanic rock outcrops. This anomaly pattern related to tertiary volcanic rock from Mount Pre-Rajabasa. The spread of moderate to the high pattern of anomalies surrounding Rajabasa Mountain is estimated as part of the volcanic product with the composition of Quaternary and Tertiary andesite lava rock.
However, what about the high anomalous response in the area of quantum volcanic rock that is predominantly dominated by tuffaceous rock and tuffaceous sandstone. If it is assumed that the absence of intrusive rocks in the area can also be interpreted that the bedrocks are approaching the surface, thus affecting the high anomalous response in the region. To show the subsurface model in the region, 2D modeling of the residual anomaly data of the research area was conducted.

\section{2D Gravity Qualitative Model}

Based on the result of the separation of the gravitational anomaly with regional gravity anomaly, we made three transverse incision profile on residual gravity anomaly data as 2D model data input on line A to A', $\mathrm{B}$ to $\mathrm{B}^{\prime}$ and $\mathrm{C}$ to $\mathrm{C}^{\prime}$. The $2 \mathrm{D}$ modeling results from the residual gravity anomaly data on line $\mathrm{A}$ to $\mathrm{A}^{\prime}$ is shown in Figure 6.

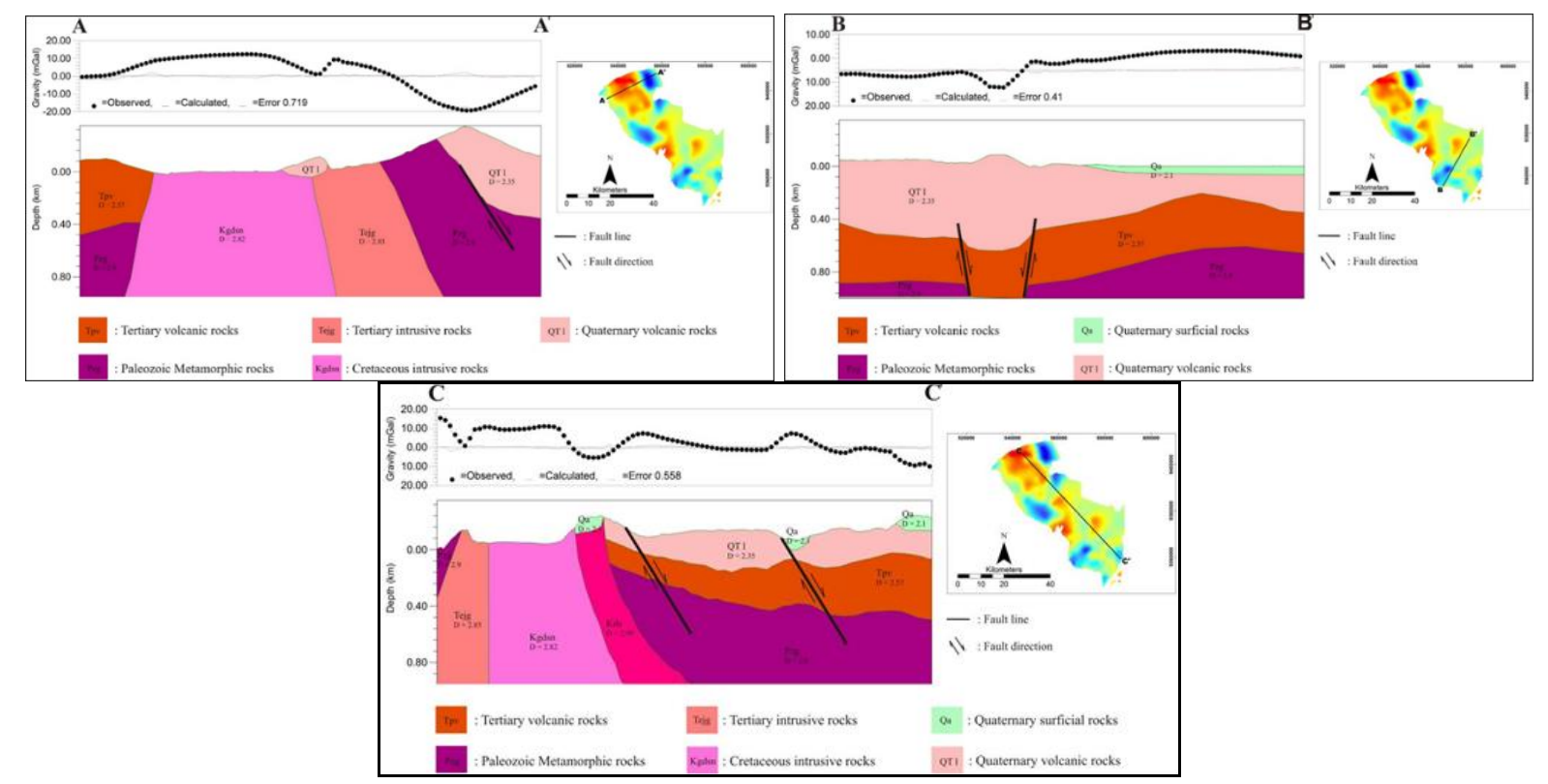

Figure 6. $\mathrm{A}$ to $\mathrm{A}^{\prime}$ is a line profile on the residual gravity anomaly of the study area (top left). Pluton granitoid Sulan with Kgdsn and Tejg codes are visible through the Pzg's bedrock. B to B' is a line profile with harmonized layers between Quaternary volcanic rocks on Tertiary volcanic rock and bedrock (top right). $\mathrm{C}$ to $\mathrm{C}^{\prime}$ is a line profile on the residual gravity anomaly of the study area. Pluton granitoid Sulan with Kgdsn, Kds, and Tejg codes are visible through the Pzg basement rocks that are suppressed in tandem by Tertiary and Quarternary volcanic rocks (bottom center).

The 2D model of this line shows the pattern of Sulan granitoid Pluton and Jatibaru granite Pluton, which intruded overlapped bedrocks by Tertiary and Quaternary volcanic rocks. Granitoid Sulan with the main components of granodiorite 
rocks intruding basement rock, which is also intruded by Tertiary granite rocks causing the gravity anomaly response in this area to be high.

Besides also caused by the exposure of bed surface rocks, this granitoid pluton also has a considerable density of about 2.82 $\mathrm{gr} / \mathrm{cm}^{3}$. With considerable volume, these plutons have the potential to be a source of material sufficient to sustain the development needs of the Sunda Strait Strategic Area. Several smaller-volume intrusive rocks are reported to be exposed south of the Sulan granitoid and to date have been mined. In addition to pluton, it is also reported as a sill of the Quaternary andesite lava with an insignificant spreading area such as in Tanjungan and Katibung areas.

Some mining companies have been exploiting the rocks of materials in the region, although not on a large scale. The fault interpretation located in the eastern part of this profile is also linked to the depression area that forms the swamps in Way Sulan. This fault is also responsible for the descent of bedding rock with an older fracture period from the Quaternary volcanic rock, which then fills the depression zone. The subsurface model in the Bakauheni area on the B to B' line shows the dominance of Quaternary volcanic rocks that lie in harmony with tertiary volcanic rock and the bedrock, as shown in Figure 6.

The process of destruction of the preRajabasa volcanic cone forming the sag basin, then becomes the path of the Rajabasa volcano with different eruption periods. Nevertheless, the dominance of volcanic rocks Quaternary cannot beat the dominance of Tertiary volcanic rocks just like that. This rock layer is also still widespread around the area Bakauheni and even revealed clearly in Panengah and Tangkil. The dominance of Quaternary volcanic rocks over tuffaceous rocks causes a lack of rock material to be obtained from these rock units.

Nevertheless, some potential of basaltic andesitic rocks can be obtained in monogenetic volcanic zones exposed around the foot of Mount Rajabasa (Darmawan et al., 2015). Unfortunately, the location is tangent to the interests of geothermal resources and community plantations. Therefore, the utilization of material potency is preferred for Tertiary volcanic rock exposed in the Bakauheni - Tangkil area. Nevertheless, some companies have exploited the raw materials in Quaternary volcanic rocks around the foot of Mount Rajabasa.

The 2D reconstruction model of Rajabasa Mountain in the Pre-Rajabasa caldera still challenging to see if they only rely on gravity anomaly data. The ambiguity characteristic of this modeling result is also still high, although still at a decent level. However, the need for additional data is a necessity to get a more detailed and comprehensive subsurface picture. Based on the subsurface model of $\mathrm{C}$ to $\mathrm{C}$ ' residual gravity anomaly incision shown in Figure 5, it is also seen that the high anomaly value in the area between Tarahan and Bakauheni is more dominated by the rise and fall of altitude. The schist bedrock has intruded by Sulan granitoid, Sekampung diorite, and Jatibaru granite. This condition also confirms the potential of material rocks from the granitoid, which is large enough in this area to be its own potential related to the fulfillment of stone raw material needs for the development of the Strategic Area of Sunda Strait.

The pattern of dispersion of tertiary and stronger volcanic rocks and rocks in this model shows a linear relationship with a uniform distribution from the Tarahan area to Bakauheni. However, a small amount of Tertiary volcanic rocks with an andesite lava composition exposed on the surface, thus minimizing the potential utilization of raw material in the study area. Therefore, it is necessary to optimize the search/exploration of volcanic rocks of Quaternary, especially those composed of andesite lava in the research area.

Based on the petrographic analysis, volcanic rocks spread along Tarahan to 
Bakauheni dominated by hornblende andesite, basalt-amphibole, and tuff. Andesite rock commonly in the dark to dark grey and brownish-grey colour are composed of hornblende and plagioclase minerals with porphyritic texture. The composition of the magma that forms the outcrop rocks in this region from AAS analysis is known as the calc-alkaline series. The partial melting process between oceanic crust and continental crust is estimated as the source of magma (Haerudin et al., 2018).

\section{CONCLUSION AND SUGGESTION}

This study has found that, generally, the spread of bedrock was identified scattered throughout Tarahan-Bakauheni. It was also shown that Tertiary volcanic rocks in the Bakauheni could be utilized to meet the development needs of the Sunda Strait Strategic Area. However, the spread of these rocks on the surface is limited only to its outcrops in the Panengahan and Tangkil regions. The second significant finding was that there is a potential of raw materials such as andesite in Ketibung and Tanjungan areas. Andesite lava is commonly found as a product of the eruption of Mount Rajabasa, which part of its territory is a national park. Therefore, it is quite difficult to utilize this rock in large quantities.

Some volcanic conduits of a monogenetic volcano around the foot of Mount Rajabasa potentially become the location of producing raw materials for the development of the area. As a suggestion, this result leads to conducting a more detailed measurement of other geophysical methods such as geoelectrical in the foot of Mount Rajabasa.

\section{ACKNOWLEDGMENT}

The authors would like to acknowledge the financial support provided by Ministry of Research and Higher Education Indonesia under the PENPRINAS MP3EI Scheme. Many thanks to Departement of Geophysics Engineering, University of Lampung for the equipment and research members for their great co-operation.

\section{AUTHOR CONTRIBUTIONS}

GL reviewing literature. AZ and IG collected data and analysed data. All authors contributed in writing the manuscript.

\section{REFERENCES}

Agustawijaya, D. S. (2019). Practical applications of strength criteria in civil engineering designs for shallow tunnels in weak rock. International Journal of Technology, 10(1), 16-26. https://doi.org/10.14716/ijtech.v10i1.28 31

Ayala, C., Bohoyo, F., Maestro, A., Reguera, M. I., Torne, M., Rubio, F., Fernàndez, M., \& García-Lobón, J. L. (2016). Updated bouguer anomalies of the Iberian Peninsula: A new perspective to interpret the regional geology. Journal of Maps, 12(5), 1089-1092.

https://doi.org/10.1080/17445647.2015. 1126538

Barber, A. J., Crow, M. J., \& Milsom, J. S. (2005). SUMATRA: Geology, resources and tectonic evolution. London: The Geological Society.

Bronto, S., Asmoro, P., Hartono, G., \& Sulistiyono, S. (2012). Evolution of rajabasa volcano in Kalianda area and its vicinity, South Lampung Regency. Indonesian Journal on Geoscience, 7(1), 11-25. https://doi.org/10.17014/ijog.v7i1.132

Darmawan, I. G. B., Setijadji, L. D., \& Wintolo, D. (2015). Geology and geothermal system in Rajabasa volcano South Lampung Regency, Indonesia (approach to field observations, water geochemistry and magnetic method). World Geothermal Congress 2015, April, 1-12.

De Coster, G. L. (1974). The geology of the Central and South Sumatra basins. Indonesian Petroleum Association. 3(1) 77-110. 
https://doi.org/10.29118/ipa.670.77.110 Giacomini, B. B., Leite, E. P., \& Crósta, A. P. (2017). 3D gravimetric investigation of the Cerro do Jarau structure, Rio Grande do Sul, Brazil. Meteoritics and Planetary Science, 52(4), 565-583. https://doi.org/10.1111/maps.12813

Girolami, C., Barchi, M. R., Heyde, I., Pauselli, C., Vetere, F., \& Cannata, A. (2017). The gravity anomaly of Mount Amiata; different approaches for understanding anomaly source distribution. Geophysical Journal International, 211(2), 865-882. https://doi.org/10.1093/gji/ggx350

Haerudin, N., Zaenudin, A., Aribowo, Y., \& Darmawan, I. G. B. (2018). Mapping and analysis of the physical properties of rocks for building materials in the Sunda Strait region. Journal of Physics: Conference Series. 1080(1), 1-7

https://doi.org/10.1088/17426596/1080/1/012035

Harahap, B. H., Abidin, H. Z., Gunawan, W., \& Yuniarni, R. (2015). Genesis of $\mathrm{Pb}-\mathrm{Zn}-\mathrm{Cu}-\mathrm{Ag}$ deposits within Permian Carboniferous-Carbonate rocks in Madina Regency, North Sumatra. Indonesian Journal on Geoscience, 2(3), 167-184. https://doi.org/10.17014/ijog.2.3.167184

Henstock, T. J., McNeill, L. C., Bull, J. M., Cook, B. J., Gulick, S. P. S., Austin, J. A., Permana, H., \& Djajadihardja, Y. S. (2016). Downgoing plate topography stopped rupture in the A.D. 2005 Sumatra earthquake. Geology, 44(1), 71-74.

https://doi.org/10.1130/G37258.1

Iqbal, M., Juliarka, B. R., Ashuri, W., \& Farishi, B. Al. (2019). Hydrogeochemistry of Natar and Cisarua hot springs in South Lampung, Indonesia. Journal of Geoscience, Engineering, Environment, and Technology, 4(3), 178. https://doi.org/10.25299/jgeet.2019.4.3.
4070

Karunianto, A. J., Haryanto, D., Hikmatullah, F., \& Laesanpura, A. (2017). Penentuan anomali gayaberat regional dan residual menggunakan filter gaussian daerah Mamuju Sulawesi Barat. EKSPLORIUM, 38(2), 89-98.

https://doi.org/10.17146/eksplorium.20 17.38.2.3921

Khan, M. R., Bilali, S. S., Hameed, F., Rabnawaz, A., Mustafa, S., Azad, N., Basharat, M., \& Niaz, A. (2018). Application of gravity and magnetic methods for the crustal study and delineating associated ores in the western limb of Hazara Kashmir Syntaxis, Northwest Himalayas, Pakistan. Arabian Journal of Geosciences, 11(6), 1-13. https://doi.org/10.1007/s12517-0183483-9

Kurnio, H. (2019). Geochemical characteristics of Sunda volcanic arc in Sumatra and Andaman. Indonesian Journal on Geoscience, 6(1), 1-16. https://doi.org/10.17014/ijog.6.1.1-16

Liu, H., Martelet, G., Wang, B., Erdmann, S., Chen, Y., Faure, M., Huang, F., Scaillet, B., le-Breton, N., Shu, L., Wang, R., \& Zhu, J. (2018). Incremental emplacement of the late jurassic midcrustal, lopolith-like qitianling pluton, South China, revealed by AMS and Bouguer gravity data. Journal of Geophysical Research: Solid Earth, 123(10), 9249-9268. https://doi.org/10.1029/2018JB015761

Lo, Y. T., Yen, H. Y., \& Chen, C. R. (2018). Correlation between the Bouguer gravity anomaly and the TAIGER tomography of the Taiwan region. Terrestrial, Atmospheric and Oceanic Sciences, 29(5), 473-483. https://doi.org/10.3319/TAO.2018.03.0 1.01

Madu, A. J. C., \& Mosto, O. K. (2016). Bouguer anomaly and free-air anomaly correlation signatures in parts of Benue 
and Kogi States of Nigeria. International Journal Geology and Mining, 2(1), 30-37.

Panjaitan, S., \& Astawa, N. (2016). Studi potensi migas dengan metode gayaberat di lepas Pantai Utara Jakarta. Jurnal Geologi Kelautan, 8(1), 23-35. https://doi.org/10.32693/jgk.8.1.2010.1 83

Purnomo, J., Koesuma, S., \& Yunianto, M. (2013). Pemisahan anomali regionalresidual pada metode gravitasi menggunakan metode moving average, polynomial dan inversion. Indonesian Journal of Applied Physics, 3(01), 1020.

https://doi.org/10.13057/ijap.v3i01.120 8

Putra, D. B. E., Samsudin, A. R., \& Choanji, T. (2016). Geophysical modelling using gravity data of meteorite impact crater at bukit bunuh, Lenggong, Perak, Malaysia. Proceeding of The 7th Indonesia Japan Joint Scientific Symposium, 7(1), 515-524.

Salapare, R. C., Dimalanta, C. B., Ramos, N. T., Manalo, P. C., Faustino-Eslava, D. V., Queaño, K. L., \& Yumul, G. P. (2015). Upper crustal structure beneath the Zambales Ophiolite Complex, Luzon, Philippines inferred from integrated gravity, magnetic and geological data. Geophysical Journal International, 201(3), 1522-1533. https://doi.org/10.1093/gji/ggv094

Setiady, D., \& Sarmili, L. (2005). Keterdapatan beberapa mineral berat di perairan pulau bintan dan sekitarnya sebagai hasil rombakan dari sedimen holosen asal paparan Sunda. Jurnal Geologi Kelautan, 3(3), 1-7. https://doi.org/10.32693/jgk.3.3.2005.1 26

Subagio, S., \& Patmawidjaya, T. (2013). Pola anomali bouguer dan anomali magnet dan kaitannya dengan prospek sumber daya mineral dan energi di pulau laut, pulau sebuku dan selat sebuku, Kalimantan Selatan. Jurnal Geologi Kelautan, 11(3), 115-130. https://doi.org/10.32693/jgk.11.3.2013. 236

Subarsyah, S., \& Priohandono, Y. A. (2009). Metoda pseudo-gravity dalam analisis kelurusan dan patahan di sekitar tinggian asahan, perairan Selat Malaka. Jurnal Geologi Kelautan, 7(2), 65-71.

https://doi.org/10.32693/jgk.7.2.2009.1 72

Timur, E., Kaftan, İ., Sari, C., \& Şalk, M. (2019). Structure of the Büyük Menderes Graben systems from gravity anomalies. Turkish Journal of Earth Sciences, 28(4), 544-557. https://doi.org/10.3906/yer-1809-31

$\mathrm{Xu}, \mathrm{C}$., Wang, H. hong, Luo, Z. cai, Ning, J. sheng, \& Liu, H. liang. (2015). Multilayer stress from gravity and its tectonic implications in urban active fault zone: A case study in Shenzhen, South China. Journal of Applied Geophysics, 114(1), 174-182. https://doi.org/10.1016/j.jappgeo.2015. 01.017

Yudhicara, Muslim, D., \& Sudradjat, A. (2017). Geomorphic analysis in determining tectonic activity affected by Sumatra Fault in Liwa region and its surrounding area, Lampung, Indonesia. Indonesian Journal on Geoscience, 4(3), 193-208. https://doi.org/10.17014/ijog.4.3.193208

Zahra, H. S., \& Oweis, H. T. (2016). Application of high-pass filtering techniques on gravity and magnetic data of the eastern Qattara Depression area, Western Desert, Egypt. NRIAG Journal of Astronomy and Geophysics, $5(1)$, 106-123. https://doi.org/10.1016/j.nrjag.2016.01. 005 


\section{Appendix}

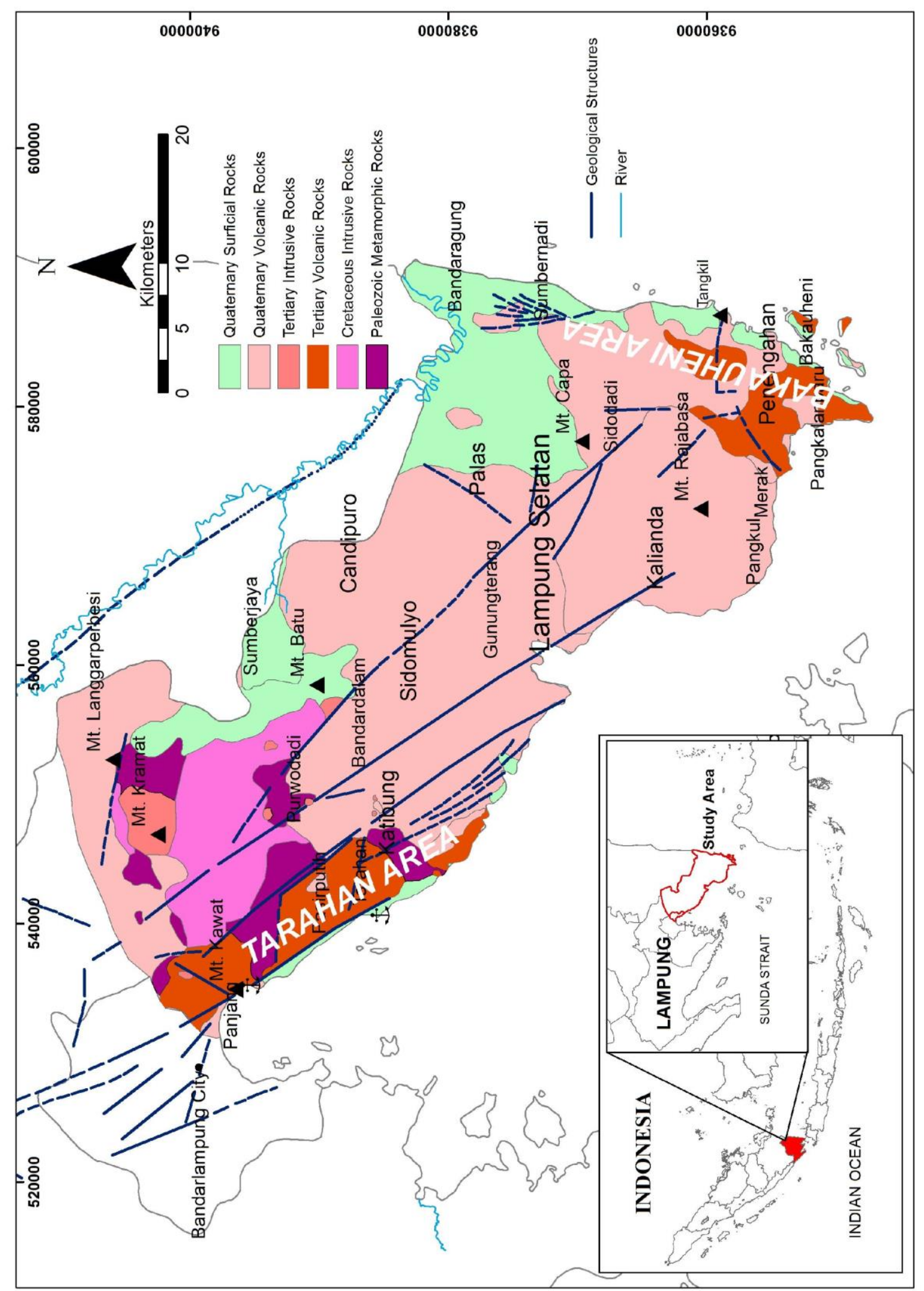

Figure 2. Geological map showing the geological conditions of the Tarahan and Rajabasa regions. There are six groups of rock from paleozoic to quaternary with volcanic, intrusive and metamorphic lithology 


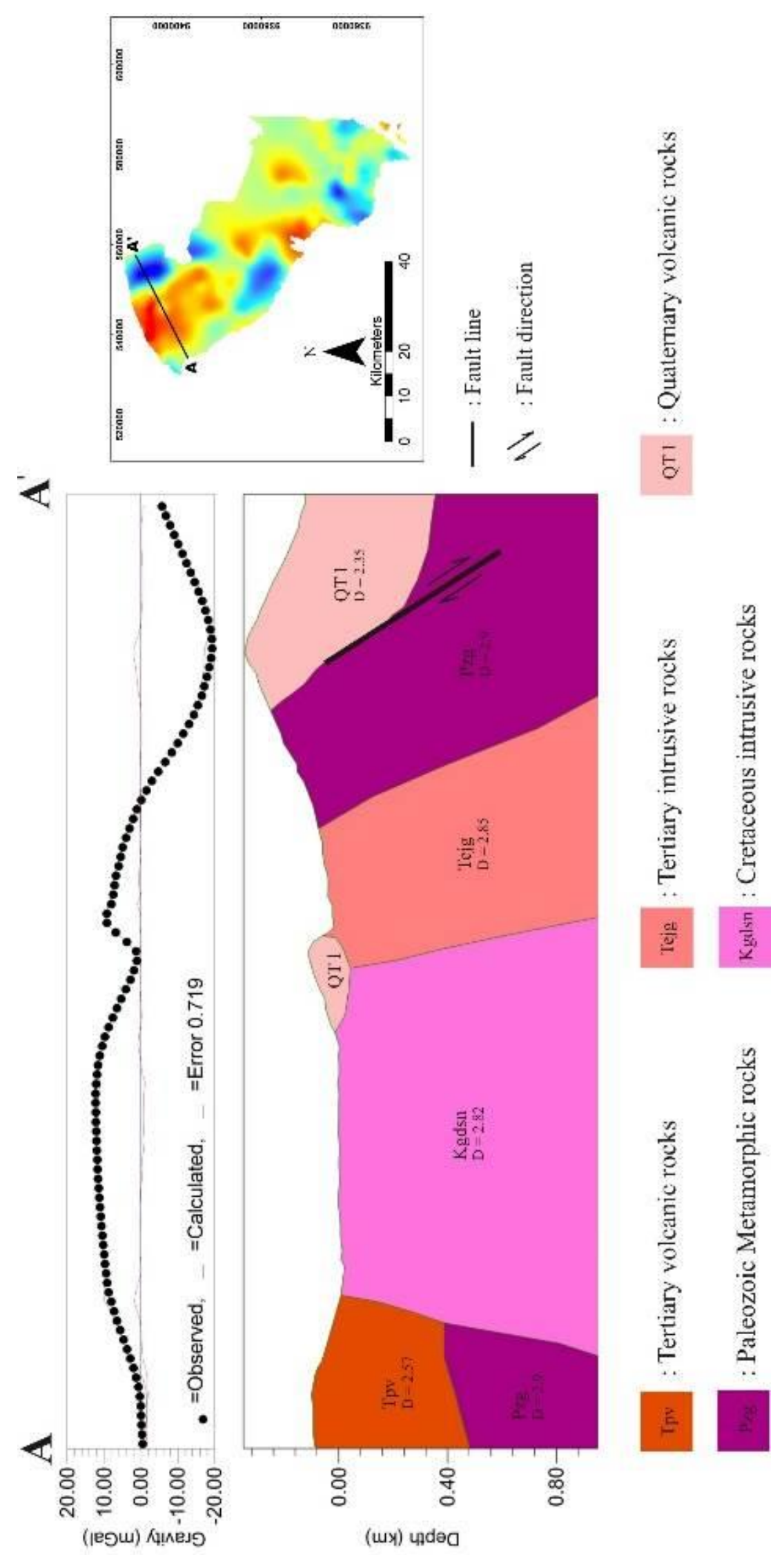

Figure 6. A to $A^{\prime}$ is a line profile on the residual gravity anomaly of the study area (top left). Pluton granitoid Sulan with Kgdsn and Tejg codes are visible through the Pzg's bedrock. 


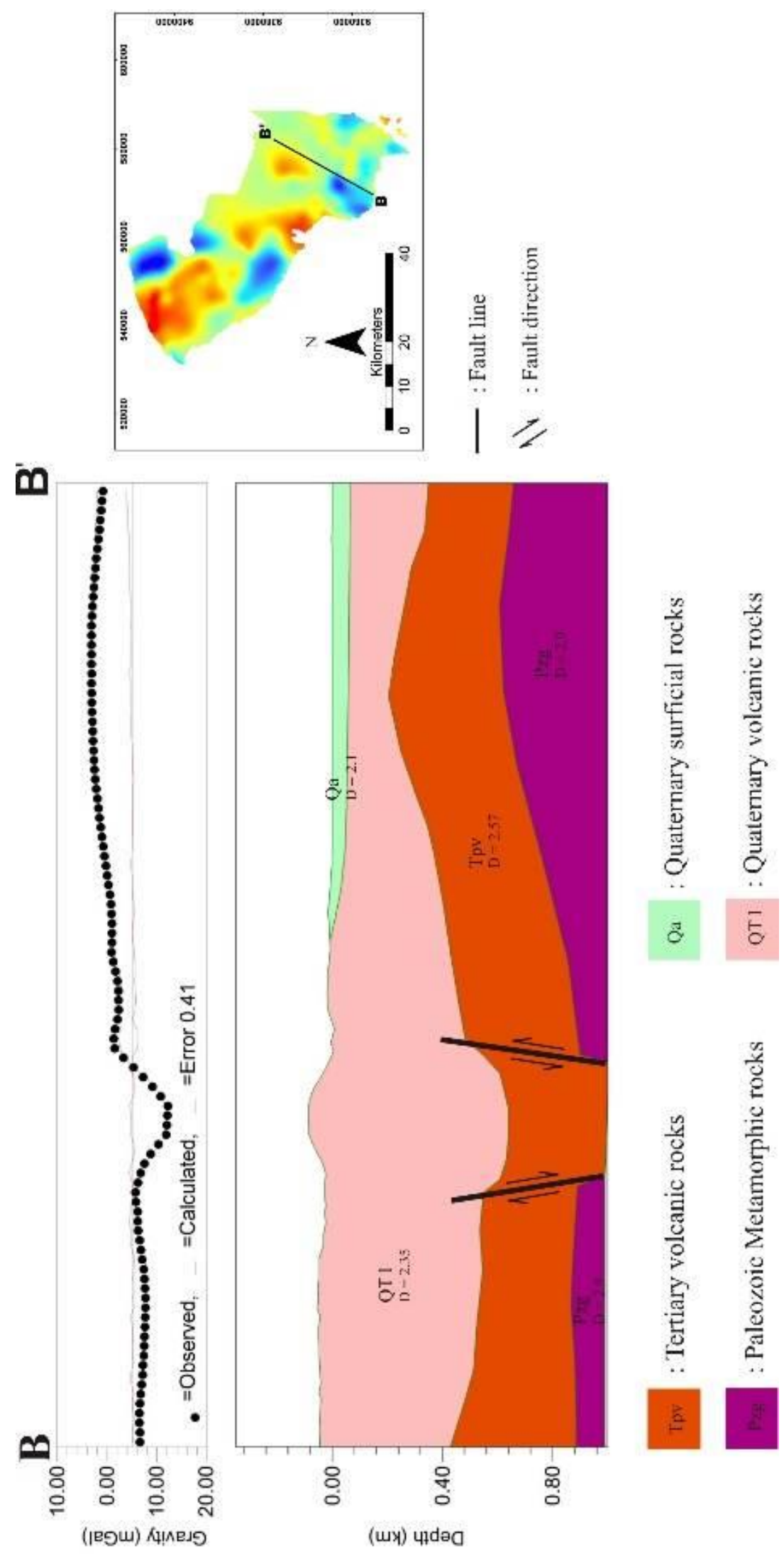

Figure 6. $\mathrm{B}$ to $\mathrm{B}^{\prime}$ is a line profile with harmonized layers between Quaternary volcanic rocks on Tertiary volcanic rock and bedrock (top right). 


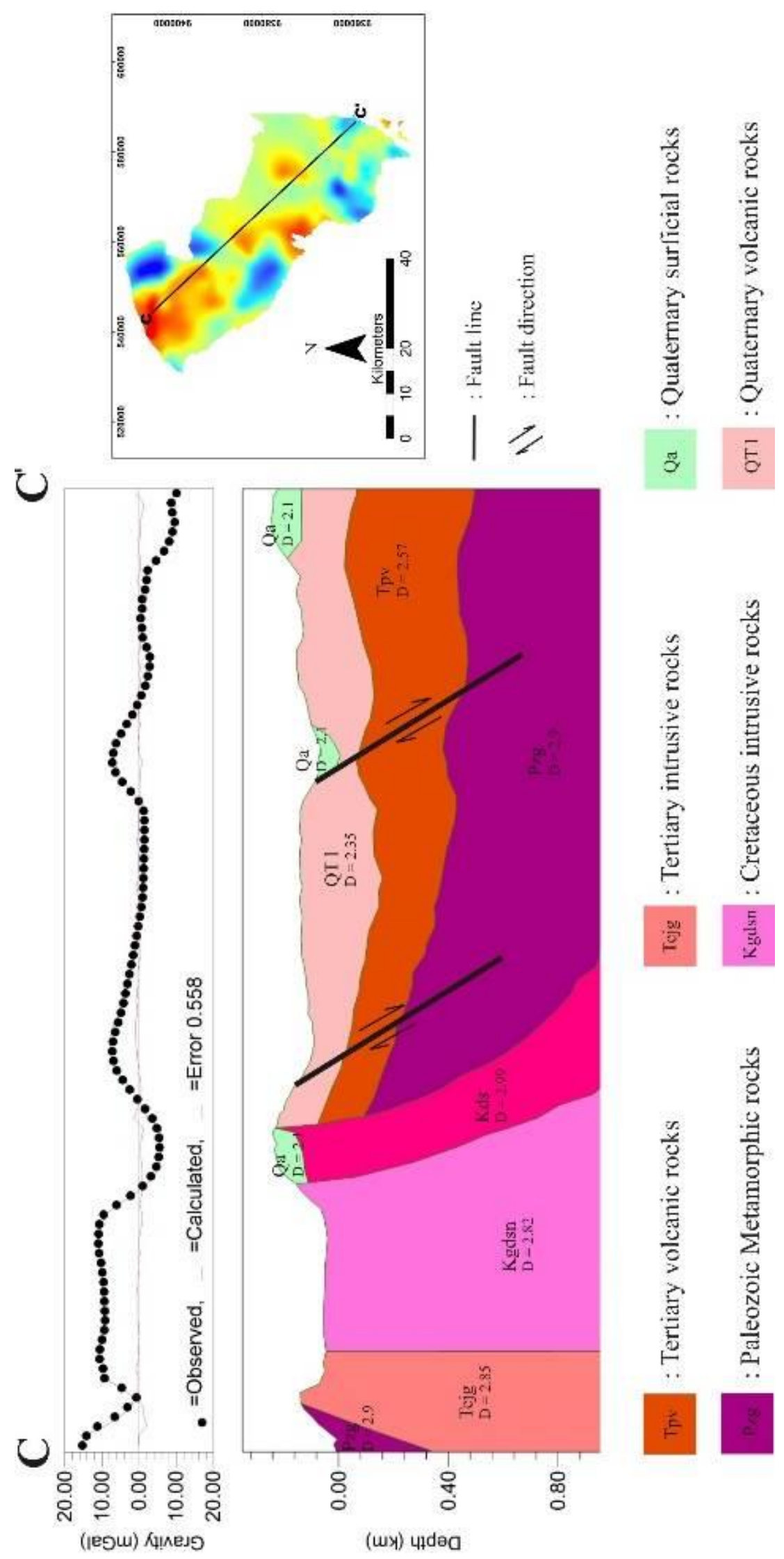

Figure 6. $\mathrm{C}$ to $\mathrm{C}^{\prime}$ is a line profile on the residual gravity anomaly of the study area. Pluton granitoid Sulan with Kgdsn, Kds, and Tejg codes are visible through the Pzg basement rocks that are suppressed in tandem by Tertiary and Quarternary volcanic rocks (bottom center). 